EWA KOCHANOWSKA*

Bielsko-Biała, Polska

ORCID ID: https://www.orcid.org/oooo-0oo3-0183-1239
Forum Pedagogiczne

$10(2020) 1$

Wpłynęło: 12.11.2019

Zatwierdzono do druku: 18.03.2020

DOI: $10.21697 /$ fp.2020.1.08

\title{
WYMIARY PROFESJONALIZMU NAUCZYCIELA WCZESNEJ EDUKACJI Z PERSPEKTYWY KANDYDATÓW DO ZAWODU
}

\begin{abstract}
Streszczenie: Nowe wyzwania generowane pod adresem edukacji nauczycielskiej w kontekście dynamicznych zmian rzeczywistości społeczno-kulturowej i technologicznej stawiają $\mathrm{w}$ coraz to nowym świetle kwestie profesjonalizmu nauczyciela. Celem niniejszego opracowania jest próba rekonstrukcji sposobów rozumienia profesjonalizmu nauczyciela wczesnej edukacji i jego wymiarów z perspektywy kandydatów do zawodu. Koncepcja badań opiera się na założeniu, że w konstruktywistycznie zorientowanej edukacji nauczycielskiej kluczową rolę odgrywa rozpoczynanie kształcenia od rekonstrukcji potocznych przekonań kandydatów na pedagogów na temat wybranych obszarów edukacji. Ujawnienie sposobów konceptualizowania i oceny profesjonalizmu nauczycieli wczesnej edukacji przez osoby rozpoczynające studia pedagogiczne pozwala na planowanie sposobów wykorzystania ich wiedzy potocznej na ten temat oraz na przewidywanie kierunków kształcenia w toku studiów. Tekst opiera się na analizie jakościowej wypowiedzi pisemnych studentów rozpoczynających studia w zakresie pedagogiki przedszkolnej i wczesnoszkolnej. Uzyskane wyniki badań, wskazujące na dominujący w wypowiedziach instrumentalny, „zamknięty” i oparty na paradygmacie nauczania sposób postrzegania profesjonalizmu nauczyciela pracującego z dziećmi w młodszym wieku szkolnym, pozwala na określenie koniecznych kierunków zmian w kształceniu przyszłych nauczycieli.
\end{abstract}

Słowa kluczowe: profesjonalizm nauczyciela; edukacja wczesnoszkolna, przekonania potoczne, kandydaci do zawodu nauczyciela.

\section{Wprowadzenie - wokół profesjonalizmu nauczyciela}

Zmieniający się świat generuje nowe wyzwania pod adresem edukacji nauczycielskiej, która w rozumieniu pedeutologii współczesnej jest „procesem wielostronnym, interdyscyplinarnym, wielofunkcyjnym i długofalowym, rozwijającym osobowość i postawy, ściśle związanym z bliskim i dalszym środowiskiem, z transformacją

* Dr hab. Ewa Kochanowska, profesor AT-H, Akademia Techniczno-Humanistyczna w Bielsku-Białej; e-mail: ekochanowska@ath.bielsko.pl. 
systemową oraz z globalnymi i polskimi wyzwaniami cywilizacyjnymi” (Banach 1996, s. 9). Dyskusja na temat pożądanych i oczekiwanych od nauczyciela kompetencji i jego profesjonalizmu przybiera na sile zwłaszcza w ostatnim czasie w związku z kolejnymi zmianami wdrażanymi w procesie ich kształcenia. Kategoria zmiany na stałe wpisana jest jednak w proces przygotowania kandydatów do zawodu nauczyciela i w kolejne etapy jego rozwoju zawodowego w ramach dokształcania i doskonalenia kompetencji. Ponadto, jak pisze Joanna M. Łukasik: „nauczyciel każdego dnia doświadcza zmiany w sytuacjach dydaktycznych, wychowawczych, jest świadkiem niepowtarzalności i zmienności, w pewnym sensie również nieprzewidywalności doświadczeń w przestrzeni własnej pracy zawodowej i równocześnie jest inicjatorem i promotorem zmiany” (2015, s. 43). Jako „osoba poddawana ciągłym bodźcom ze środowiska społeczno-edukacyjnego, funkcjonująca w świecie dyskursu" (Sikora 2016, s. 73), nauczyciel projektuje i realizuje własną aktywność pedagogiczną, formułuje przekonania na jej temat pozwalające mu na subiektywną interpretację rzeczywistości, zakłada określoną koncepcję ucznia, a tym samym wskazuje sposób, w jaki interpretuje proces uczenia się (Grochowalska 2012).

W kontekście złożoności, kompleksowego i zmiennego charakteru pracy nauczyciela (Potulicka 2016), rodzą się pytania: jak kształcić nauczycieli, aby umieli sprostać stawianym im dzisiaj i w przyszłości zadaniom? W czym wyraża się istota profesjonalizmu współczesnego nauczyciela? W rozważaniach polskich pedeutologów (Dróżka 2010; Gołębniak 1998; Kwiatkowska 2008; Lewowicki 2007; Mizerek 1999; Potulicka 2015) na temat nurtów i orientacji edukacji nauczycielskiej oraz profesjonalizmu nauczyciela, jak i w zagranicznych koncepcjach wyznaczających współczesne kierunki kształcenia nauczycieli, takich jak: humanistyczna koncepcja kształcenia nauczycieli A.W. Combsa i in. (1978), refleksyjnej praktyki Donalda Schöna (1983), profesjonalnego artyzmu Delli Fish (1988), transformatywnego intelektualisty Henry'ego Giroux (1988) czy np. mądrego nauczania Allana Feldmana (1997), zaznacza się wyraźnie odejście od technicznej racjonalności jako podstawy przygotowania zawodowego nauczyciela na rzecz samoświadomości i refleksji jako wyznacznika profesjonalizmu. Autorzy wymienionych koncepcji są zgodni, że profesjonalizm nauczyciela wymaga przedefiniowania w kierunku większej refleksyjności, introspekcji, głębokiego wglądu w każdą interakcję z uczniem (Copinathan 2008). Zmieniające się cele zawodu nauczyciela wyznaczają nową wersję jego profesjonalizmu, opartą na możliwości ciągłego samokształcenia, radzeniu sobie z różnicami oraz na dochodzeniu do zgody podczas współpracy koleżeńskiej, w relacjach z uczniami, rodzicami i w czasie kontaktów pozazawodowych (Nixon i in. 1997).

Joanna Madalińska-Michalak (2014) zwraca uwagę na dwie perspektywy w podejściu do profesjonalizmu nauczyciela. Pierwsza koncentruje się na działaniu nauczyciela i pełnionych przez niego rolach, zaangażowaniu oraz przestrzeganiu określonych standardów pracy i wymogów etyki zawodowej. W ramach drugiej perspektywy przedmiotem zainteresowania czyni się status zawodowy nauczycieli, 
prestiż, ich wykształcenie i fachowe przygotowanie absolwentów studiów pedagogicznych do wykonywania pracy. Próbę połączenia obu perspektyw stanowi wizja nauczyciela, którego charakteryzuje nie tyle fachowość na wzór zawodów technicznych i nie zespół czynności społecznie użytecznych, wymagających od nauczyciela odpowiedniej wiedzy i umiejętności, ile przede wszystkim spełnianie - poprzez długotrwały proces kształcenia i przygotowania oraz doskonalenia zawodowego - wysokich standardów poznawczych, działaniowych i etycznych.

W ogólnym znaczeniu profesjonalizm rozumiany jest jako „fachowość, biegłość w wykony waniu jakiegoś działania, znajomość rzeczy odnosząca się do spełniania wysokich standardów wykonywania zawodu, w zgodzie z wszystkimi regułami sztuki, jakie się na niego składają. Reguły te odnoszą się do wieloaspektowej wiedzy teoretycznej i praktycznej, jaka tworzy zestaw kompetencji warunkujących optymalne wywiązywanie się z podejmowanej roli zawodowej” (Kwatera 2015, s. 29). Na gruncie nauk społecznych pojęcia profesjonalizmu i profesji odnoszone są często tylko do wybranych zawodów, które charakteryzują się określonym zestawem cech posiadanych/reprezentowanych przez grupę, wśród których wymienia się (Urbaniak-Zając, Piekarski 2015):

- przynależność do profesji, poprzedzoną długotrwałym, teoretycznie ugruntowanym i specjalistycznym wykształceniem;

- podległość normom etycznym;

- pracę profesjonalistów służącą dobru wspólnemu;

- autonomię wykonywania zawodu w odniesieniu do klientów i instytucji (kontrola m.in. standardów kształcenia i udzielanie dostępu do wykonywania zawodu);

- traktowanie profesjonalisty jako eksperta, który posiada naukowe i praktyczne kompetencje;

- połączenie profesjonalistów w samorządne organizacje zawodowe, stojące na straży obrony interesów grupy.

Wymienione wyżej cechy odnoszą się także do zawodu nauczyciela. Profesjonalizm nauczycielski sam w sobie „,jest swoistego rodzaju wartością, o którą warto zabiegać, gdyż pozwala on na zmianę nie tylko profesjonalnej kultury edukacyjnej nauczycieli, ale także zewnętrznego wizerunku profesjonalizmu w dziedzinie publicznej oświaty" (Madalińska-Michalak 2016, s. 300). Postrzegany jest i definiowany w kontekście różnych konstruktów teoretycznych, z których każdy wskazuje na jego odmienne fundamentalne wartości (Melosik 1995). Na podstawie analizy współczesnych podejść w dyskursie wokół profesjonalizmu, Bogusława Dorota Gołębniak i Beata Zamorska stwierdzają: „Przegląd współczesnych podejść do profesjonalizmu, prowadzić może do wrażenia, jak niewiele, w gruncie rzeczy, w stosunku do dyskursu z minionego wieku, tu się zmieniło. Ciągle mamy do czynienia ze zmaganiem się dyskursu zarządzania z dyskursem autonomii i etyczności. Z drugiej jednak strony, nie sposób nie dostrzec i twórczych rozwinięć (podejścia klasycznego i nowego profesjonalizmu) oraz emergencji (wyłaniania się) 
nowych podejść, wychodzących poza zastaną opozycję" (2014, s. 39). Dzieje się tak dlatego, że profesja nauczycielska uwarunkowana jest kontekstem i wymaga się od nauczyciela szybkiego reagowania na dokonujące się w świecie zmiany społeczne i cywilizacyjne. Obecnie nauczyciel staje wobec wielu wyzwań cywilizacyjnych i edukacyjnych. Oczekuje się od niego, że będzie:

- „sprawcą” zmiany, tj. osobą, która ma poczucie wpływu na przebieg zachodzących zdarzeń i sytuacji edukacyjnych oraz świadomie i aktywnie w tychże zmianach uczestniczy;

- refleksyjny, czyli podejmie trud czynienia namysłu nad własnym postępowaniem zawodowym, warsztatem pracy, będzie umieć z dystansem spojrzeć na podejmowane przez siebie działania oraz dokona ich obiektywnej oceny;

- „otwartym umysłem”, który poddaje krytycznej analizie rzeczywistość edukacyjną i jej kontekst społeczno-kulturowy oraz poddaje w wątpliwość funkcjonujące rozwiązania;

- „wewnątrzsterowny”, tzn. podejmuje działania dla satysfakcji wynikającej z samej aktywności, kieruje się kompetencjami i jest świadomy swojej wiedzy i działań;

- twórczy, innowacyjny - przekracza schematy, wykazuje inicjatywę i oryginalność w swoim myśleniu i działaniu;

- odpowiedzialny, analizuje konsekwencje, do których mogą doprowadzić podejmowane działania;

- $\quad$ szczery w analizie i ocenie celów oraz konsekwencji własnych działań (Nowak-Dziemianowicz 2001).

Sprostanie wyżej wymienionym wymaganiom i uczenie się roli zawodowej przez nauczyciela jest długotrwałym i złożonym procesem, uwarunkowanym różnorodnymi czynnikami, w tym m.in. przekonaniami i sposobami postrzegania zawodu i profesjonalizmu nauczyciela. Henryka Kwiatkowska (2008) wskazuje na konieczność spełnienia przez nauczyciela wysokich standardów poznawczych, działaniowych i etycznych, które stanowią zarazem o wymiarze jego profesjonalizmu. Zalicza do nich:

- $\quad$ wymiar poznawczy jako kompetencję w zakresie wiedzy nauczyciela, na którą składa się wiedza ogólna i specjalistyczna nauczyciela oraz umiejętność świadomego i efektywnego działania;

- wymiar działaniowy, rozumiany jako kompetencja praktyczna nauczyciela obejmująca pracę o charakterze instrumentalnym i/lub twórczym;

- wymiar etyczny, czyli wrażliwość i odpowiedzialność moralną nauczyciela.

Syntezę wymienionych wyżej wymiarów profesjonalizmu nauczyciela stanowi kolejno wymieniany, tj. pasja, której wskaźnikiem jest poczucie przez nauczyciela sensu tego, co robi - sensu wynikającego z połączenia myśli, działania i wyników tego działania (Walkiewicz 2015). Wymiary profesjonalizmu nie są mierzalne i można je uchwycić dopiero z „perspektywy zewnętrznej (w przestrzeni) i późniejszej (czas)” (Gołębniak 2012, s. 490). 
W kontekście podjętych w tekście analiz i rozważań pojęcie profesjonalizmu odnoszone jest do „procesu krystalizowania się oczekiwań społecznych w stosunku do rzeczywistych kwalifikacji i kompetencji zawodowych nauczyciela na rzecz optymalizacji podejmowanych przez niego działań" (Englund 1996). Tak więc na obraz profesjonalizmu nauczyciela mają wpływ oczekiwania różnych grup społecznych, począwszy od samych nauczycieli po inne podmioty edukacji, takie jak: rodzice, uczniowie itd. Swoje wizje profesjonalizmu nauczyciela mają także kandydaci do tego zawodu. Jak podkreśla A. Kwatera: „Profesjonalizacja zawodowa nauczyciela rozpoczyna się już w momencie, kiedy dana osoba powodowana swoimi zainteresowaniami czy przeświadczeniami o słuszności takiego wyboru, świadomie podejmuje decyzję o chęci wykonywania tego zawodu i stawia ukierunkowane kroki, aby zdobyć kompetencje i kwalifikacje do jego rzetelnego, efektywnego, zgodnego ze społecznymi oczekiwaniami, a także, co nie mniej ważne, satysfakcjonującego wykonywania” (Kwatera 2015 s. 23). Podobnie jak w przypadku nauczycieli praktyków, kandydaci do zawodu mają swoje oczekiwania związane z przebiegiem pracy zawodowej. Prowadzone w tym obszarze w ostatnich latach badania (Watoła 2015; Chmiel 2014; Krasoń 2012; Nowicka 2016 i in.) wskazują, że studenci kierunków pedagogicznych postrzegają zawód nauczyciela z perspektywy własnych doświadczeń edukacyjnych. Ich wizje pracy nauczyciela głęboko osadzone są w paradygmacie prymatu nauczania nad uczeniem się. Co więcej, sami studenci już w trakcie studiów często oczekują zestawu zaleceń wprowadzonych w trybie dyrektywno-nakazowym, który zapewnia im „poczucie bezpieczeństwa” w pracy pedagogicznej.

Jednym ze źródeł potocznych przekonań studentów na temat profesjonalizmu nauczyciela są retrospektywne doświadczenia własne studentów jako uczniów (Ferenz 2018, s. 17). Swoje wyobrażenia budują, odwołując się do pozytywnych i negatywnych wspomnień odnoszących się do szkoły i relacji z nauczycielami (Kutrowska 2008). W trakcie studiów kandydaci do zawodu nauczyciela konfrontują swoje przekonania o profesjonalizmie nauczyciela $\mathrm{z}$ wiedzą teoretyczną i obserwacjami poczynionymi w ramach praktyk pedagogicznych. Proces stawania się nauczycielem rozpoczyna się od pojawienia się motywacji do wyboru zawodu oraz jej dojrzewania, aż do pełniejszej identyfikacji z zawodem, i dokonuje się przez cały okres aktywności zawodowej (Dróżka, Madalińska-Michalak 2016). Tak więc nauczyciel nie staje się profesjonalistą po jakimś skończonym procesie kształcenia, dokształcania czy doskonalenia zawodowego, ponieważ wyróżnikiem nauczycielskiej profesji jest proces „stawania się” nauczycielem. Ujawnienie sposobów konceptualizowania i oceny profesjonalizmu nauczycieli wczesnej edukacji przez osoby rozpoczynające studia pedagogiczne pozwala na planowanie sposobów wykorzystania ich wiedzy potocznej na ten temat oraz na przewidywanie kierunków kształcenia w toku studiów. 


\section{Wymiary profesjonalizmu nauczyciela edukacji wczesnoszkolnej - procedura i wyniki badań}

Celem niniejszego opracowania jest próba rekonstrukcji sposobów rozumienia profesjonalizmu nauczyciela i jego wymiarów przez kandydatów do zawodu nauczyciela. Tekst opiera się na analizie danych jakościowych zgromadzonych w toku badań przeprowadzonych wśród studentów rozpoczynających studia pedagogiczne na kierunku pedagogika przedszkolna i wczesnoszkolna. Koncepcja badań opiera się na założeniu, że edukacja nauczycielska rozpoczyna się od działania, które pozwala ujawnić wiedzę studentów podejmujących studia pedagogiczne, wynikającą z restrukturyzacji ich uprzednich i aktualnych doświadczeń związanych z edukacją, pozwala zarysować scenariusz kolejnych kroków edukacyjnych (Gołębniak 1998). Jak pisze Marzenna Nowicka: „Dla rozwoju nauczycielskiej wrażliwości ważne jest, aby studenci, zanim jeszcze rozpoczną projektowanie pracy z uczniami, mogli konfrontować swoje przekonania i poddać je analizom na zajęciach. Stwarza to możliwość oceny własnych doświadczeń, zrekonstruowania swoich teorii oraz antycypacji ich pedagogicznych skutków" (2016, s. 153). Uwzględnienie w procesie kształcenia potocznych przekonań, określających to, „co człowiek myśli o otaczającej rzeczywistości, jak ją spostrzega, rozumie i ocenia" (Lachowicz-Tabaczek 2004, s. 15), wpływa na efektywność przyswajania wiedzy naukowej w toku studiów.

Dobór badanej grupy był celowy. Badaniami objęto 56 studentów (w tym 54 kobiety i dwóch mężczyzn) pierwszych lat licencjackich studiów stacjonarnych i niestacjonarnych dwóch uczelni publicznych na Podbeskidziu. Żadna z osób badanych nie kończyła wcześniej kursów ani klas o profilu pedagogicznym. Badania zostały przeprowadzone w październiku i listopadzie 2018 roku. Planując projekt badawczy, odwołano się do strategii jakościowej i wykorzystano metodę analizy dokumentów (Rapley 2010). Dokumenty w formie wypowiedzi pisemnych na temat: Profesjonalny nauczyciel wczesnej edukacji zostały wytworzone intencjonalnie na użytek badania. Teksty analizowane były w podejściu nieustrukturyzowanym, które polega na tym, że badacze jakościowi „nie próbują kierować się żadnymi wcześniej ustalonymi zasadami analizy. Czytając kilkakrotnie materiał empiryczny, próbują znaleźć „kluczowe tematy i tym samym naszkicować obraz założeń i znaczeń, składających się na kulturowy świat, którego częścią są analizowane teksty" (Denzin, Lincoln 2009, s. 326). Dokonano analizy materiału badawczego w postaci 56 prac pisemnych. W toku badań poszukiwano odpowiedzi na następujące pytania problemowe: (1) Jakie znaczenia nadają studenci określeniu profesjonalizm nauczyciela wczesnej edukacji? i (2) Jaki jest sposób rozumienia przez studentów wymiarów profesjonalizmu nauczyciela?

W celu wydobycia $\mathrm{z}$ wypowiedzi kategorii porządkujących przekonania na temat profesjonalizmu nauczyciela, zgodnie z procedurą badań jakościowych, na podstawie analizy wypowiedzi badanych, dokonano zestawienia zakresów treści odnoszących się do następujących obszarów: 
- $\quad$ sposoby rozumienia profesjonalizmu nauczyciela wczesnej edukacji;

- rozumienie wymiaru poznawczego profesjonalizmu, wyznaczonego określonym stosunkiem profesjonalnego nauczyciela do wiedzy pedagogicznej i psychologicznej z zakresu edukacji wczesnoszkolnej jako dziedziny przedmiotowej i stosunkiem do własnej wiedzy;

- rozumienie działaniowego wymiaru profesjonalizmu współokreślonego stosunkiem odtwórczym lub twórczym do działań własnych i ucznia;

- rozumienie osobowościowego i etycznego wymiaru profesjonalizmu wyrażonego charakterystycznymi cechami profesjonalnego nauczyciela i jego postawą moralną.

W podejściu badanych studentów do istoty profesjonalizmu nauczyciela dało się wyodrębnić trzy zasadnicze kierunki, które można określić w przejściu od paradygmatu nauczania do paradygmatu uczenia się.

\section{Profesjonalizm nauczyciela wczesnej edukacji „mierzony” wykształceniem, poziomem awansu zawodowego, stażem pracy i doświadczeniem zawodowym}

Zgodnie z pierwszym wyodrębnionym sposobem rozumienia wyznacznikiem profesjonalizm nauczyciela jest posiadanie przez niego odpowiedniego wykształcenia, wysokiego stopnia awansu zawodowego i doświadczenia w pracy zawodowej. Profesjonalizm jest w tym przypadku łączony z ukończeniem studiów magisterskich i posiadaniem dodatkowych kwalifikacji poświadczonych dyplomem lub świadectwem. Badane studentki wyraźnie podkreślały rolę czynnika czasu, tzn. wieloletniego stażu pracy zawodowej w osiągnięciu statusu nauczyciela profesjonalisty oraz łączyły profesjonalizm ze zdobywaniem przez nauczyciela kolejnych szczebli awansu zawodowego. Wypowiadały się pisemnie o tym w następujący sposób $^{1}$ : „Nauczyciel, który dopiero zaczyna pracę albo krótko pracuje, nie jest jeszcze profesjonalistą. Musi przepracować dobrych parę lat w szkole. Na stażu ma swojego opiekuna, bez niego często jeszcze nie wie, co robić”. „Kiedy już nauczyciel jest doświadczony w zawodzie, skończy różne szkolenia i kursy albo dodatkowo studia podyplomowe, to można powiedzieć, że zostaje profesjonalistą".

\section{Profesjonalizm „techniczny” - sprawność metodyczna w działaniu}

Zgodnie z drugim podejściem badanych studentek do istoty profesjonalizmu nauczyciela wczesnej edukacji, które często współwystępowało z pierwszym, jego istota wyraża się w skuteczności działania, posiadaniu przez nauczyciela odpowiedniego zasobu wiedzy i opanowaniu takiego repertuaru działań, który pozwala mu sprawnie i szybko reagować na sytuacje dydaktyczno-wychowawcze w przedszkolu

1 Przykładowe wypowiedzi pisemne zostały przytoczone w dosłownej formie, bez korekty językowej. 
lub szkole. Profesjonalizm traktowany był w tym przypadku jako wypróbowana skuteczność działania, umiejętność sprostania wymaganiom zewnętrznym (przepisom) przez nauczyciela. Przykłady wypowiedzi badanych: „Profesjonalny nauczyciel czuje się pewny w tym co robi i nie musi się zastanawiać jak rozwiązać różne problemy. Ma już taką wiedzę i jest tak doświadczony, że doskonale wie co robić w każdej sytuacji”. „Profesjonalista świetnie realizuje swoje obowiązki zawodowe jako nauczyciel. Wie, jak postąpić, gdy w pracy napotyka na trudności, nie musi się długo zastanawiać, planując zajęcia i potem kiedy je prowadzi. Działa szybko i sprawnie. Jak zmienia się coś w edukacji, bo wchodzi np. jakaś reforma, to od razu wie, jak się dostosować".

Przytoczone wypowiedzi wskazują na techniczne, wykonawcze podejście badanych studentek do funkcjonowania zawodowego nauczyciela-profesjonalisty. Jest to podejście charakterystyczne dla tzw. fundamentalistycznego podejścia do myślenia o szkole i nauczycielach jako aplikatorach założeń „odgórnie” zadanych, którzy potrafią podporządkować się założeniom, regułom i rolom narzuconym przez przepisy i wymagania odgórne (Rodziewicz 1994). Badane studentki podkreślały w tym ujęciu profesjonalizmu dobre metodyczne przygotowanie nauczyciela do zawodu. W tym rozumieniu nauczyciel profesjonalista to „nauczyciel rzemieślnik”, który stosuje sprawdzone, wypróbowane sposoby działania. Przytoczne wyżej sposoby rozumienia profesjonalizmu zakładają, że kwalifikacje nauczycielskie, będące wyznacznikiem profesjonalizmu nauczyciela, mają charakter zamknięty, tzn. można dokładnie określić zakres, rodzaj wiedzy i umiejętności składające się na pełne kwalifikacje zawodowe profesjonalnego nauczyciela, a tym samym opracować wzorzec przygotowania zawodowego nauczycieli i określić kolejne etapy jego doskonalenia w drodze do punktu kulminacyjnego, jakim jest „uzyskanie statusu profesjonalnego nauczyciela”.

\section{Profesjonalizm „otwarty” - gotowość na zmiany i twórcze działania}

Odmienna wizja profesjonalizmu nauczyciela wczesnej edukacji została zarysowana w wypowiedziach kolejnej grupy studentek, które, odwołując się do własnych negatywnych doświadczeń edukacyjnych, opisywały działania nauczycielek/nauczycieli, których z pewnością - w ich ocenie - nie można nazwać profesjonalistami. Przeciwieństwem profesjonalizmu są w tym przypadku według badanych: rutyna, brak kreatywności, brak otwartości na nową wiedzę związaną z postępem w różnych dziedzinach wiedzy, a także z rozwojem cywilizacyjnym i technologicznym. Poniżej przykład wypowiedzi: „Nauczycielka, która mnie uczyła w klasach I-III, nie potrafiła mnie zmotywować do nauki. Zajęcia przebiegały stale tak samo, a najważniejsze były: kartkówki, sprawdziany i odpytywanie. Nudne zajęcia, prawie cały czas z podręcznikiem. Na nasze pytania i uwagi często reagowała negatywnie. Takie postępowanie nauczyciela na pewno nie jest profesjonalne”. „Profesjonalny nauczyciel nie działa szablonowo, cały czas szuka nowych pomysłów, jak uczyć. 
Jest zafascynowany tym, co robi. Uczenie dzieci sprawia mu przyjemność, daje dużo radości nie tylko jemu, ale i dzieciom. Taki nauczyciel wprowadza nowości w szkole, cały czas jest autentycznie zainteresowany tym, co czuje i robi uczeń".

Główny zarzut stawiany nauczycielom, których nie można nazwać profesjonalistami, dotyczył braku otwartości na zmiany. Na gotowość nauczyciela na zmiany zachodzące w otaczającej rzeczywistości, ale także zmiany odnoszące się do warsztatu pracy, jako na wyznaczniki profesjonalizmu nauczyciela, wskazują pedeutolodzy, którzy twierdzą, iż nie jest możliwe takie przygotowanie nauczyciela do pracy, które od razu czyniłoby go profesjonalistą. Nauczyciel działa w sytuacjach niepowtarzalnych, otwartych i oddziałuje na strukturę otwartą, częściowo tajemniczą, niepoznawalną, jaką jest człowiek (Kwaśnica 1994). Magdalena Grochowalska pisze: „W byciu nauczycielem - nie tylko małego dziecka -chodzi nie tyle o wpisanie się w przepis roli, w normatywne wymagania, zestawy kompetencji do spełnienia, których dostarcza także sama pedagogika, ile o wypracowanie strategii interpretacyjnych i definicji sytuacji w nowej rzeczywistości społecznej” (2014, s. 31). W tym ujęciu, profesjonalny nauczyciel stale podnosi swoją wiedzę i doskonali umiejętności, poszukuje ciekawych rozwiązań, stosuje urozmaicone rozwiązania dydaktyczno-wychowawcze i jest autentycznie zainteresowany tym, jak przebiega proces uczenia się dziecka. Centralną kategorią profesjonalizmu otwartego jest refleksja nad własnym działaniem (Gołębniak 2005).

W wypowiedziach badanych studentów pojawiały się stwierdzenia, które można odnieść do czterech wymiarów profesjonalizmu nauczyciela, przy czym w ich ramach - różnice w sposobie rozumienia.

1) poznawczy wymiar profesjonalizmu nauczyciela

Istotą profesjonalizmu nauczyciela jest, według wszystkich badanych studentek, odpowiedni poziom i rodzaj wiedzy posiadanej przez nauczyciela. W wypowiedziach pojawiały się odniesienia do kilku obszarów wiedzy, z których najczęściej wskazywana była wiedza na temat metodyki kształcenia, wychowania i opieki nad dzieckiem w młodszym wieku szkolnym, np. „Nauczyciel profesjonalista musi wiedzieć jak pracować z dziećmi w szkole, co robić, jakie metody stosować. Tylko wtedy zrealizuje dobrze swoje działania".

Ponadto większość badanych podkreśliła znaczenie wiedzy edukacyjnej profesjonalnego nauczyciela o procesach kształcenia i wychowania dziecka. Przykład wypowiedzi studentki: „Na studiach przyszły nauczyciel zdobywa wiedzę o tym, jak dobrze uczyć dzieci, czego dzieci w tym wieku potrzebują w szkole, jakie mają potrzeby, jak reagować na ich różne zachowania. I to jest bardzo ważne. Profesjonalny nauczyciel ma bogatą wiedzę pedagogiczną i psychologiczną".

Badane studentki podkreślały znaczenie kompetencji merytorycznych profesjonalnego nauczyciela, przy czym bardzo rzadko ich wypowiedzi wskazywały na rozumienie przez nich, jak ważne jest wypracowanie przez nauczyciela strategii 
interpretacyjnych i definicji sytuacji w nowej rzeczywistości społecznej. Są one związane z „edukacyjnym rozumieniem - wzmacnianym wiedzą pedagogiczną, wspierającym nauczyciela w dokonywaniu doboru strategii i wyzwalającym jego zdolność do rozpoznawania moralnych aspektów decyzji i działania (Gołębniak 1998). Wiedza nauczyciela rozumiana jest częściej przez badanych jako zasób wiadomości o procesie edukacji niż jako proces stałego jej konstruowania i rekonstruowania. Takie podejście dalekie jest od profesjonalizmu zgodnego z konstruktywistyczną wizją zawodu nauczyciela.

\section{2) działaniowy wymiar profesjonalizmu nauczyciela wczesnej edukacji}

W wypowiedziach badanych studentek dało się wyróżnić dwa podejścia do działań nauczyciela, tj. instrumentalne i twórcze. Pierwsze z nich wyrażało się w podkreślaniu znaczenia umiejętności adekwatnego doboru metod i technik działania przez nauczyciela, odpowiednio do przewidywanych skutków działania. Umiejętność stosowania sprawdzonych, wypróbowanych sposobów działania dydaktycznego, wychowawczego i opieki nad dziećmi jest dla badanej grupy studentek wskaźnikiem profesjonalizmu nauczyciela. Przykład wypowiedzi: „Profesjonalista dokładnie wie, jak zrealizować to, co wcześniej sobie zaplanuje. Ma swoje sprawdzone i wypróbowane sposoby pracy, szybko podejmuje decyzje, potrafi działać w każdej sytuacji”.

Zaskakujące jest to, że mimo iż studenci często dzielili się w swoich wypowiedziach własnymi negatywnymi doświadczeniami szkolnymi związanymi z rutyną i schematycznością działania swoich nauczycieli, sami jednak, charakteryzując profesjonalizm nauczyciela, koncentrowali się na jego praktycznych umiejętnościach, typowo technicznym, metodycznym i realizacyjnym sprawstwie nauczycieli.

Drugie podejście charakteryzowały wypowiedzi akcentujące znaczenie kreatywności nauczyciela w obszarze poszukiwania nowych rozwiązań metodycznych, umiejętności samodzielnego projektowania zajęć i autorskich programów kształcenia. Co więcej, w opinii badanych, kompetencje metodyczne powinny stanowić obszar permanentnego doskonalenia pedagogicznego warsztatu pracy profesjonalnego nauczyciela. Wypowiedź badanej: „Profesjonalny nauczyciel jest twórczy. Robi wszystko, aby dzieci nie nudziły się. Stale coś zmienia w sposobie swojej pracy, szuka czegoś nowego, ciekawego dla uczniów. Sam wymyśla ciekawe projekty, programy nauczania i wprowadza je w życie".

Warto podkreślić, iż w wypowiedziach studentek nie stwierdzono odniesień do wielu innych umiejętności nauczyciela, akcentowanych w edukacji konstruktywistycznie zorientowanej, takich jak np. zdolność do „profesjonalnej kolegialności” (Gołębniak 1998), czyli współpracy z innymi podmiotami edukacji czy umiejętność dokonywania refleksji nad własną praktyką edukacyjną. 
3) osobowościowy i etyczny wymiar profesjonalizmu nauczyciela

Przeprowadzone badania pokazują, że obok wiedzy i umiejętności wskaźnikami profesjonalizmu nauczyciela są dla wszystkich badanych studentek: pasja, inicjatywa, wrażliwość na drugiego człowieka i jego potrzeby oraz zaangażowanie i entuzjazm w pracy pedagogicznej. Kluczową rolę odgrywają także: szacunek dla uczniów i otwartość na interakcje z nimi. Przykład wypowiedzi badanej: „Profesjonalny nauczyciel „żyje swoją pracą”. Widać, że kocha pracę z dziećmi i kontakt z nimi daje mu wiele radości”. „Nauczyciel powinien traktować dziecko z takim szacunkiem jak osobę dorosłą, zawsze wysłuchać. U profesjonalisty widać, że angażuje się całym sobą w pracę z dziećmi”.

Swoisty potencjał osobowościowy - zdaniem studentek - powinien współwystępować u profesjonalnych nauczycieli z ich nienaganną postawą moralną i wysokim poziomem etycznym, jeśli chodzi o postępowanie w pracy zawodowej i w życiu prywatnym. Etyczny wymiar zawodu wiążą badane głównie z kulturą osobistą, uczciwością i sprawiedliwym, obiektywnym podejście do każdego ucznia.

Na podstawie przedstawionych wyników badań można stwierdzić, że w sposobie rozumienia profesjonalizmu nauczyciela wczesnej edukacji występuje tendencja do instrumentalnego, technologicznego podejście do jego kompetencji. Zarysowane wizje profesjonalnego nauczyciela mają swoje źródło przede wszystkim we własnych doświadczeniach studentów jako uczniów. Postrzegają oni istotę profesjonalizmu nauczyciela w kategoriach pasji, powołania, odpowiedzialności za rozwój i edukację ucznia. Większość z badanych ujmuje jednak cele pracy nauczyciela poprzez prymat nauczania nad uczeniem się.

\section{Zakończenie}

Osoba podejmująca studia na kierunku pedagogicznym nauczycielskim ma określone oczekiwania, wyobrażenia i nastawienia wobec charakteru podejmowanego kształcenia, a także posiada choćby ogólnie zarysowany obraz przyszłej roli zawodowej. Wcześniejsze doświadczenia związane z byciem uczniem wydają się nie tylko oczywiste, ale i najlepsze do wykorzystania w trakcie zdobywania kwalifikacji zawodowych (Bullough 2009). Zarówno kandydat do zawodu nauczyciela, jak i nauczyciel aktywny zawodowo „musi umieć dokonać krytycznego zasobu posiadanej wiedzy i wyuczonych sprawności, a oprócz tego, co jest niełatwe, a jest niezwykle ważne - musi być gotowy do rozstania się z tą wiedzą i z tymi sprawnościami, które w odmienionych warunkach działania, nie służąc rozumieniu czy wyjaśnianiu nowych zdarzeń, problemów w jego pracy, nie sprzyjają tym samym sprawnemu działaniu" (Gołębniak, Kwiatkowska 2013). Uzyskane wyniki badań nad profesjonalizmem nauczyciela w potocznych przekonaniach studentów pedagogiki przedszkolnej i wczesnoszkolnej skłaniają do wniosku, że w kształceniu kandydatów do zawodu nauczyciela wskazane jest położnie większego akcentu 
na kształtowanie rozumienia profesjonalizmu nauczyciela jako kategorii otwartej, a nie „ograniczonej”, określonej wyłącznie poziomem wykształcenia, awansu zawodowego i doświadczeniem zawodowym. Konieczne jest przygotowanie studentów do zrozumienia konieczności i istoty zmian edukacyjnych, których będą ambasadorami i realizatorami jednocześnie. W tym kontekście zadaniem uczelni kształcących przyszłych nauczycieli jest rozwijanie ich kreatywności, umiejętności konstruktywnej adaptacji do świata permanentnych zmian i gotowości do całożyciowej edukacji. Przedstawiona analiza wypowiedzi pisemnych studentów rozpoczynających studia nauczycielskie odsłania ich podejście do wiedzy i umiejętności metodycznych nauczyciela i traktuje je jako jeden z głównych wyznaczników profesjonalizmu nauczyciela wczesnej edukacji. Stwierdzona tendencja do instrumentalnego umetodycznienia edukacji wczesnoszkolnej przez badanych już na początku studiów tym bardziej budzi niepokój, że w codziennym życiu i działaniach szkoły edukacja początkowa także pozostaje w znacznej mierze w obszarze barier wyznaczanych przez instrumentalny dyskurs, który jest nadal reprodukowany w literaturze metodycznej (Bałachowicz, Witkowska-Tomaszewska 2015). Myślenie o edukacji jako o praktyce technicznej może prowadzić do marginalizowania znaczenia wiedzy teoretycznej (np. ogólnopedagogicznej i psychologicznej) w pracy nauczyciela.

Nadal zatem pozostaje aktualne postulowane od wielu lat odejście od dominującej nader często orientacji technologicznej w kształceniu nauczycieli w kierunku edukacji humanistycznej (Murawska 1995), akcentującej indywidualność ucznia, znaczenie dialogu w edukacji oraz nastawionej na wspieranie szeroko rozumianego osobowego wzrostu ucznia; edukacji funkcjonalnej, której istotą jest przekładanie szerokiej wiedzy teoretycznej na operacje działania praktycznego i wreszcie aksjologiczne.

\section{Bibliografia}

Bałachowicz J., Witkowska-Tomaszewska A. (2015). Edukacja wczesnoszkolna $w$ dyskursie podmiotowości. Studium teoretyczno-empiryczne. Warszawa: Wydawnictwo APS.

Banach C. (1996). Koncepcja edukacji nauczycielskiej - postulaty i realia. W: System kształcenia pedagogów specjalnych. Ciagłość i możliwości zmian. Wyczesany J., Kosętka H. (red.). Kraków: Wydawnictwo Naukowe WSiP.

Bullough R.V. (2009). Początkujący nauczyciel. Studium przypadku. Gdańsk: Gdańskie Wydawnictwo Psychologiczne.

Dróżka W., Madalińska-Michalak J. (2016). Droga do zawodu nauczyciela i motywy jej wyboru - $w$ świetle autobiograficznych wypowiedzi studentów studiów pedagogicznych. „Forum Oświatowe”, nr 28 (1). Dostępny na: http://forumoswiatowe. $\mathrm{pl} /$ index.php/czasopismo/article/view/416 (otwarty: 6.11.2019), s. 161-179. 
Chmiel T.B. (2014). Wizje i (re)wizje przygotowania do zawodu nauczyciela. Wrocław: Wydawnictwo DSW.

Combs A.W., Blume R., Newman A.J., Wass H.L. (1978). The Professional Education of Teachers. A Humanistic Approach to Teacher Preparation. Boston: Allyn and Bacon.

Copinathan at al. S. (2008). Transforming teacher education. Redefining professionals for 21st century school. Singapor: National Institute of Educational.

Denzin K.N., Lincoln S.Y. (2009). Metody badań jakościowych. Warszawa: Wydawnictwo Naukowe PWN.

Dróżka W. (2010). Wspomaganie rozwoju zawodowego nauczycieli. Zarys problematyki. W: Proces stawania się nauczycielem: teoria i praktyka. Bogaj A., Dróżka W. (red.). Kielce: Wszechnica Świętokrzyska.

Dróżka W., Madalińska-Michalak J.M. (2016). Droga do zawodu nauczyciela i motywy jej wyboru $-w$ świetle autobiograficznych wypowiedzi studentów studiów pedagogicznych. „Forum Oświatowe”, 28 (1). Dostępny na: http://forumoswiatowe.pl/ index.php/czasopismo/article/view/416 (otwarty: 7.11.2019), s. 161-179.

Dylak S. (2000). Konstruktywizm jako obiecujaca perspektywa w kształceniu nauczycieli. W: Współczesność a kształcenie nauczycieli. Kwiatkowska H., Lewowicki T. (red.). Warszawa: Wydawnictwo WSP ZNP.

Englund T. (1996). Areprofessionalteachers a goodthing? W: Teachers' professionallives. Goodson I., Hargreaves A. (red.). London: Falmer.

Feldman A. (1997). Varieties of Wisdom in Practice of Teachers. „Teaching and Teacher Education", nr 13 (7).

Ferenz K. (2018). Osobiste koncepcje pedagogii a preferowane modele pomocy. „Konteksty Pedagogiczne”, nr 1 (10), s. 13-24.

Fish D. (1988). Turning Teaching into Learning: TRIST and the Development of Professional Practice. London: West London Press

Giroux H. (1988). Teachers as Intellectuals. Towards a Critical Pedagogy of Learning. Westport, Conn: Bergin and Garvey.

Gołębniak B.D. (2005).Konstruktywizm - moda, „nowa religia” czy tylko/aż interesujaca perspektywa poznawcza i dydaktyczna? „Problemy Wczesnej Edukacji”, nr 1, s. 13-20.

Gołębniak B.D. (2012). Między naturalnym eksperymentowaniem a przygodnym aktywizmem. „Rewitalizacja” badań w działaniu w „przełomowej przyszłości”. W: „Po życie sięgać nowe...” Teoria a praktyka edukacyjna. Urlińska M.M., Uniewska A., Horowski J. (red.). Toruń: Wydawnictwo Adam Marszałek.

Gołębniak B.D. (1998). Zmiany edukacji nauczycieli. Wiedza - biegłość - refleksyjność. Toruń-Poznań: Wydawnictwo Edytor.

Gołębniak B.D., Kwiatkowska H. (2013). Nauczyciele: programowe (nie)przygotowanie. Wrocław: Wydawnictwo DSW.

Gołębniak B.D., Zamorska B. (2014). Nowy profesjonalizm nauczycieli. Podejściapraktyka - przestrzeń rozwoju. Wrocław: Wydawnictwo DSW. 
Grochowalska M. (2012). Przyszyli nauczyciele wczesnej edukacji wobec dyskursywności pedagogiki. W: Z zagadnień profesjonalizacji nauczycieli wczesnej edukacji $w$ dobie zmian. Bałachowicz J., Szkolak A. (red.). Kraków: Wydawnictwo Libron.

Grochowalska M. (2014). Dylematy nowicjusza. Konteksty stawania się nauczycielem edukacji przedszkolnej. „Edukacja Elementarna w Teorii i Praktyce”, nr 31, s. $27-40$.

Klus-Stańska D. (2010a). Dydaktyka wobec chaosu pojęć i zdarzeń. Warszawa: Wydawnictwo Akademickie "Żak”.

Klus-Stańska D. (2010b). Dzień jak co dzień. O barierach zmiany kultury szkoły. W: Wychowanie. Pojęcia procesy konteksty. Dudzikowa M., Czerepaniak-Walczak M. (red.). Gdańsk: GWP.

Krasoń K. (2012). Kształcenie nauczycieli - pytania niechciane czy konieczne? Reinterpretacja kompetencji pedagogicznych na przykładzie poziomu edukacji wczesnoszkolnej. W: Edukacja jutra. Wyzwania współczesności i przyszłości. Kamińska A., Łuszczuk W., Oleśniewicz P. (red.). Sosnowiec: Oficyna Wydawnicza Humanitas.

Kutrowska B. (2008). Spojrzenie na rolę nauczyciela z perspektywy rożnych oczekiwań społecznych. W: Nauczyciel: misja czy zawód? Społeczne i profesjonalne aspekty roli. Rudnicki P., Kutrowska B., Nowak-Dziemianowicz M. (red.). Wrocław: Wydawnictwo DSW.

Kwaśnica R. (1994). Wprowadzenie do myślenia. O wspomaganiu nauczycieli w rozwoju. Wrocław: Wrocławska Oficyna Wydawnicza.

Kwatera A. (2015). Mozaikowe ujęcie profesjonalizmu nauczyciela. W: Przygotowanie do wykonywania zawodu nauczyciela. W strone edukacji spersonalizowanej. Kowal S., Mądry-Kupiec M. (red.). Kraków: Wydawnictwo internetowe e-bookowo.

Kwiatkowska H. (2008). Pedeutologia. Warszawa: WAiP.

Lachowicz-Tabaczek K. (2009). Emocje umystu: rola potocznych koncepcji świata $i$ natury ludzkiej w regulacji percepcji $i$ zachowania. W: Psychologia poznania społecznego. Nowe idee. M. Kossowska, M. Kofta (red.). Warszawa: Wydawnictwo Naukowe PWN.

Lewowicki T. (2007). Problemy kształcenia i pracy nauczycieli. Warszawa-Radom: Instytut Technologii Eksploatacji - PIB.

Łukasik J.M. (2015). Edukacja nauczyciela refleksyjnego przez zdarzenia krytyczne. W: Przygotowanie do wykonywania zawodu nauczyciela. W strone edukacji spersonalizowanej. Kowal S., Mądry-Kupiec M. (red.). Kraków: Wydawnictwo internetowe e-bookowo.

Madalińska-Michalak J. (2014). Profesjonalizm nauczyciela. „Meritum. Mazowiecki Kwartalnik Edukacyjny", nr 1 (32), s. 2-10.

Madalińska-Michalak J. (2016). Etyka nauczyciela. W: Etyka: filozoficzna etyka życia spełnionego. Janeczek S., Starościc A. (red.). Lublin: Wydawnictwo KUL. 
Melosik Z. (1995). Postmodernistyczne kontrowersje wokół edukacji. Poznań-Toruń: Wydawnictwo Edytor.

Mizerek H. (1999). Dyskursy współczesnej edukacji nauczycielskiej: między tradycjonalizmem a ponowoczesnością. Olsztyn: Uniwersytet Warmińsko-Mazurski.

Murawska A. (1995). O sensie pracy nauczyciela. Jak kształcić przyszłych nauczycieli? „Pedagogika Szkoły Wyższej”, nr 5, s. 131-135.

Nixon J., McKreown P., Ranson S. (1997). Towards a learning profession. Changing codes of Occupational practice within the new management of Education. „British Journal of Sociology of Education", 18 (1), s. 5-28.

Nowak-Dziemianowicz M. (2001). Oblicza nauczyciela. Oblicza szkoły. Toruń: Wydawnictwo Adam Marszałek.

Nowicka M. (2016). Wartości w świecie dziecka w przekonaniach dorosłych-przyszłych nauczycieli. „Problemy Wczesnej Edukacji”, nr 2 (33), s. 152-165.

Pankowska D. (2015). Praca nauczyciela nad własnym rozwojem zawodowym. W: Skuteczna edukacja szkolna w kontekście zadań nauczyciela-wychowawcy. Pankowska D., Sokołowska-Dzioba T. (red.). Lublin: Wydawnictwo UMCS.

Potulicka E. (2016). Zmiana koncepcji kształcenia nauczycieli jako podstawa reform edukacji. „Studia Edukacyjne”, nr 38, s. 215-226.

Rapley T. (2010). Analiza konwersacji, dyskursu i dokumentów. Warszawa: Wydawnictwo PWN.

Rodziewicz E. (1994). Szkoły myślenia w edukacji. W: Edukacja wobec zmiany społecznej. Brzeziński J., Witkowski L. (red.). Poznań-Toruń: Wydawnictwo Edytor.

Schön D.A. (1982). The Reflectiwe Practicioner. New York: Basic Books.

Sikora A. (2016). Model nauczyciela wobec współczesnych sytuacji edukacyjnych. „Pedagogika Przedszkolna i Wczesnoszkolna”, vol. 4, nr 1 (7), s. 57-75.

Urbaniak-Zając D., Piekarski J. (2015). Koncepcja badań empirycznych. W: Akademickie kształcenie pedagogów w procesie zmiany. Perspektywy teoretyczne i doświadczenia absolwentów. Urbaniak-Zając D., Piekarski J. (red.). Kraków: Oficyna Wydawnicza „Impuls”.

Walkiewicz J. (2015). Pełna moc możliwości. Gliwice: Wydawnictwo Helion.

Watoła A. Oczekiwania, rzeczywistość oraz perspektywy w procesie przygotowania zawodowego nauczycieli - raport $z$ badań w polskich i norweskich placówkach oświatowych. „Problemy Profesjologii”, nr 2, s. 159-170. 


\title{
DIMENSIONS OF THE EARLY EDUCATION TEACHER'S PROFESSIONALISM IN THE STUDENTS' COMMON BELIEFS
}

\begin{abstract}
New challenges generated for teacher education in the context of dynamic changes in socio-cultural and technological reality are putting the issues of the teacher's professionalism in a new light. The purpose of this study is an attempt to reconstruct ways of understanding the professionalism of an early education teacher and its dimensions from the perspective of pre-service teachers. The concept of research is based on the assumption that starting education by reconstructing the common beliefs of the candidates for teachers about selected areas of education plays a key role in the constructivist-oriented teacher education. Revealing ways to conceptualize and assess the professionalism of early education teachers by those who begin pedagogical studies allows for planning ways of using their common knowledge on this subject and to predict directions of their studies. The text is based on a qualitative analysis of written statements by students starting studies in the area of pre-school and early school education. Obtained research results that indicate a dominating perception of the professionalism of the teacher working with children at the early school age allow to determine the necessary directions of changes in the education of future teachers. This perception visible in teachers' statements are instrumental, "closed" and based on a selected teaching paradigm.
\end{abstract}

Keywords: teacher's professionalism; early school education; common beliefs; candidates for teachers. 